\title{
Distribution of multidrug-resistant Salmonella spp. recovered from aquatic environment of Banda Aceh, Indonesia
}

\author{
SUHARTONO SUHARTONO", YULIA SARI ISMAIL, ZAHRATUL AINI \\ Department of Biology, Faculty of Mathematics and Natural Sciences, Universitas Syiah Kuala. Jl. Tgk. Syech Abdurrauf No. 3, Darussalam, Banda \\ Aceh 23111, Aceh, Indonesia. Tel./fax.: +62-651-7410248, "email: suhartono@unsyiah.ac.id
}

Manuscript received: 8 December 2020. Revision accepted: 19 January 2021.

\begin{abstract}
Suhartono S, Ismail YS, Aini Z. 2021. Distribution of multidrug-resistant Salmonella spp. recovered from aquatic environment of Banda Aceh, Indonesia. Biodiversitas 22: 881-886. The occurrence of pathogenic bacteria in an aquatic system might increase waterborne infections including salmonellosis. This might raise a concern related to the increasing pathogenic bacteria, including the multidrug-resistant Salmonella spp. in the two major rivers, namely Lamnyong and Krueng Aceh crossing the city of Banda Aceh, Indonesia. The objectives of the present study were to isolate and enumerate Salmonella spp. recovered from aquatic environment in Banda Aceh and to determine their antibiotic susceptibility. Bacterial enumeration was performed using most probable number (MPN) method followed by bacterial isolations using selective media Salmonella-Shigella Agar (SSA); whereas, antibiotic susceptibility test was conducted using a procedure as recommended by the National Committee for Clinical Laboratory Standards. There was no significant Salmonella spp. densities/mL of both locations $(\mathrm{p}=0.200)$ although, on average there was about 441.67 Salmonella spp. MPN/mL in Krueng Aceh as opposed to $20.47 \mathrm{MPN} / \mathrm{mL}$ of Lamnyong river. There were 57 Salmonella spp. isolates recovered in the sampling sites, i.e. 38 isolates of Lamnyong and 19 isolates of Krueng Aceh. The results of antibiotic susceptibility tests showed that Salmonella spp. isolates recovered from Lamnyong and Krueng Aceh showed antibiotic resistance to azithromycin, tetracycline, and streptomycin. Moreover, Salmonella spp. isolates also showed high resistance to ofloxacin, ciprofloxacin, dan ceftriaxone. All Salmonella spp. isolates were classified as MDR with the number of isolates resistant to 4-6 antibiotics was 33 (57.9\%), whereas those that were resistant to 7-9 antibiotics and over 10 antibiotics were $23(40.4 \% \%)$ and $5(8.8 \%)$ respectively. The prevalence of MDR Salmonella spp. in the current study suggest that river remain the major reservoirs for the transmission of the pathogen in aquatic systems. An appropriate assessment and monitoring are necessary to reduce the potential health risks and to ensure water quality in the aquatic environment.
\end{abstract}

Keywords: Aquatic environment, multidrug-resistant, Salmonella

Abbreviations: MDR: multi-drug resistant, MPN: most probable number, RVS: Rappaport-Vassiliadis Soya, SSA: Salmonella-Shigella Agar, XLD: Xylose Lysine Deoxycholate

\section{INTRODUCTION}

Dissemination and persistence of antibiotic-resistant bacteria in the aquatic environment remain alarming with respect to public health. Proportionally, the bacteria emerge in the environment because of higher concentrations of anthropogenic contaminants, including human and animal pollution from wastewater treatment facilities, municipal water systems, animal husbandry, agriculture, and pharmaceutical industries (Rath and Patra 2018). Additionally, the occurrence of selective pressure on contaminants, i.e. the existence of antibiotics in the aquatic environment, may select bacteria that have antibiotic resistance determinants to spread and persist in the water body, enabling them to spread their resistance to other bacteria through lateral gene transfers (Allen et al. 2010).

The occurrence of pathogenic bacteria in an aquatic system might implicate increasing water-borne infections including salmonellosis. The infections are etiologically caused by Salmonella spp., prominent Gram-negative bacilli that are notoriously associated with symptoms ranging from mild gastrointestinal issues, enteric fever to death. It is estimated that Salmonella-related infections are responsible for 93.8 million cases of gastroenteritis with approximately 155,000 deaths worldwide annually (Majowicz et al. 2010). Previous study revealed that 20 percent of all Salmonella-related typhoidal cases (130 cases in total) in Indonesia required hospitalization which was intermediate as compared to other Asian countries, i.e., high in India and Pakistan; low in China and Viet Nam (Ochiai et al. 2008). Even though Salmonella spp. are prevalently found in meat, egg, poultry products, as well as, fresh produces (Liu et al. 2018), the bacteria particularly those exhibiting antimicrobial resistance are also detected in (contaminated) surface water (Kadykalo et al. 2020; Massinai et al. 2019). The rise of antimicrobial-resistant Salmonella spp. is associated with increased adverse effects including higher hospital levels, prolonged illness and higher risk of invasive disease, as well as treatment failures during hospitalization (Hazards 2009).

Banda Aceh is one of the emerging coastal cities in Indonesia. It has a moderate population of 270,320 in 2020 with a population density of 4,410 per $\mathrm{km}^{2}$ and an annual population growth rate of 1.97 percent (BPS 2020). In 
addition, some major rivers across the city of Banda Aceh, including the Lamnyong and Krueng Aceh rivers, primarily receive effluents from residentials, hotels, markets and home industries, leading to a substantial increase in domestic pollutants (Hadi et al. 2018). Furthermore, the rivers also receive floating inorganic waste, such plastic debris in considerable amounts as a result of mismanaged land-based plastic waste (Agustina et al. 2020). This might raise a concern related to the increasing pathogenic bacteria, including the multidrug resistance Salmonella spp To the best of our knowledge, this is the first study investigating the occurrence of multidrug-resistant Salmonella spp. isolates recovered from major rivers crossing the city of Banda Aceh. Hence, the objectives of the present study were to isolate and enumerate Salmonella spp. recovered from aquatic environment in Banda Aceh, Indonesia.

\section{MATERIALS AND METHODS}

\section{Study area and water sample collection}

The location of water sampling sites in the current study is depicted in Figure 1. The water samples were collected in two primary rivers crossing Banda Aceh City, Indonesia, namely the Lamnyong river and Krueng Aceh river. The water samples were aseptically collected on the designated sampling sites using sterile $500 \mathrm{~mL}$ Schott Duran bottles. All bottles were clearly labelled containing information of serial number, types of water sample as well as time and date of collections. All samples were placed in ice-cool boxes and then transported to the laboratory for further analysis within $24 \mathrm{~h}$.

\section{Bacterial enumeration and isolation}

Salmonella spp. enumeration within water samples was performed using three series-tube most probable number (MPN) method. A $25 \mathrm{~mL}$ of water sample was added to Erlenmeyer flask containing $225 \mathrm{~mL}$ of buffer peptone water before it was diluted into tubes with final concentration of $10^{-3}$ and incubated at $37{ }^{\circ} \mathrm{C}$ for $24 \mathrm{hr}$. After incubation, the tubes positive for bacterial growth were then used for enumeration using the MPN table and $0.1 \pm 0.02 \mathrm{~mL}$ of the culture from the positive tubes was then transferred to other tubes containing $10 \mathrm{~mL}$ of Rappaport-Vassiliadis Soya (RVS) for pre-enrichment and incubated for $24 \mathrm{hr}$ at $42^{\circ} \mathrm{C}$. A loopful of the culture was then inoculated to a plate containing Xylose Lysine Deoxycholate (XLD) and incubated at $37^{\circ} \mathrm{C}$ for $24 \mathrm{~h}$. The single colonies growing in the plates were then reinoculated into Salmonella-Shigella Agar (SSA) for confirmation.

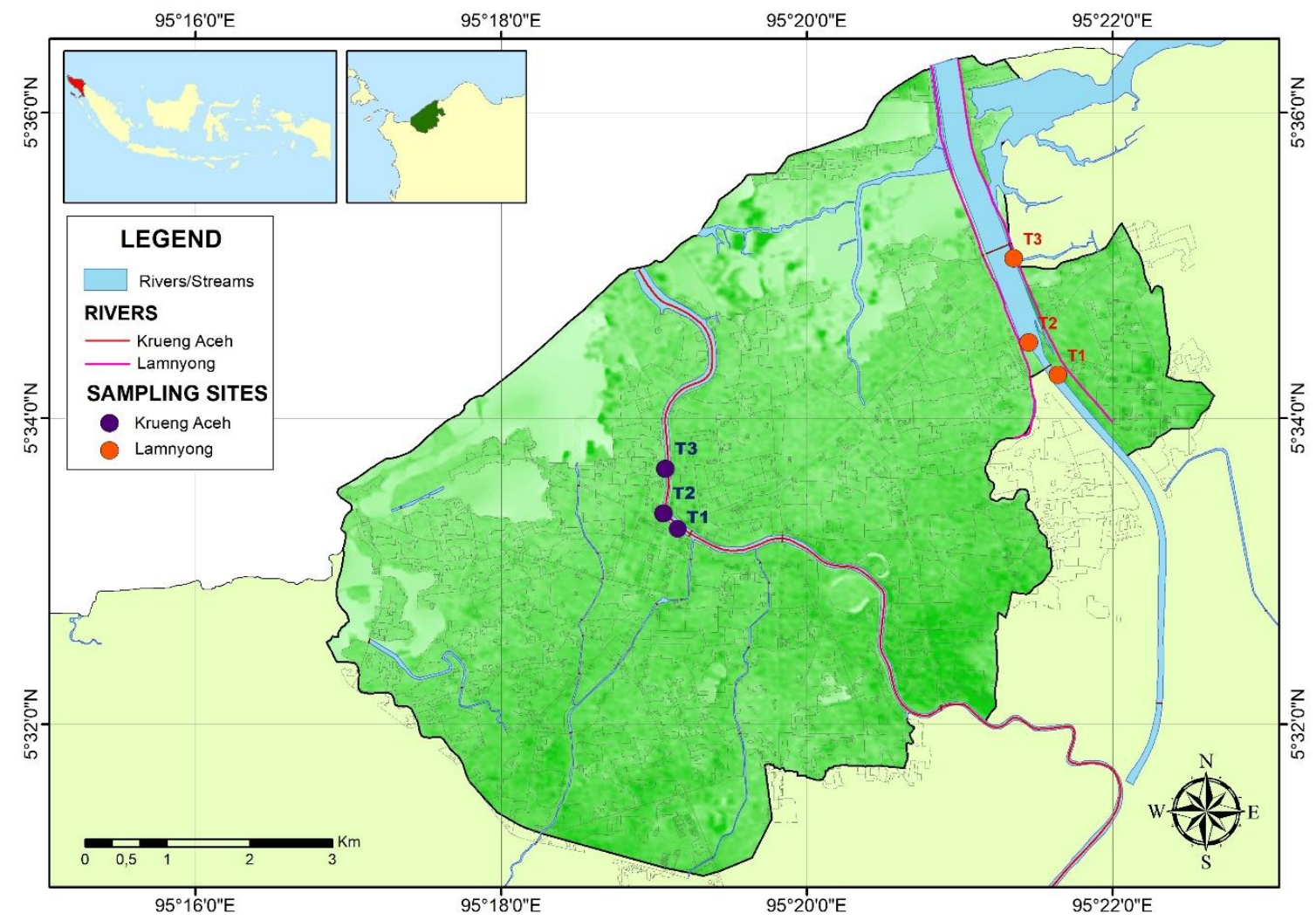

Figure 1. The sampling sites in Banda Aceh, Indonesia, vis. Lamnyong river (point 1 (T1): 5०34'15.6"N 95 $21^{\circ} 39.6^{\prime \prime} \mathrm{E}$; point 2 (T2): $5^{\circ} 34^{\prime} 30.0^{\prime \prime} \mathrm{N} 95^{\circ} 21^{\prime} 28.8^{\prime \prime E}$; and point 3 (T3): $5^{\circ} 35^{\prime} 02.4^{\prime \prime} \mathrm{N} 95^{\circ} 21^{\prime 2} 21.6^{\prime \prime E}$ ) and Krueng Aceh (point 1 (T1): $5^{\circ} 33^{\prime} 16,7^{\prime \prime} \mathrm{N} 95^{\circ} 19^{\prime} 09,4^{\prime \prime} \mathrm{E}$; point 2 (T2): 5³3'22,7"N 95¹9'03,7"E; and point 3 (T3): 5³3'40,2"N 95¹9'04,5"E) 
For isolation, $25 \mathrm{~mL}$ of water samples were mixed with $225 \mathrm{~mL}$ buffered peptone water and incubated at $37^{\circ} \mathrm{C}$ for $24 \mathrm{hr}$. One $\mathrm{mL}$ of the pre-enrichment culture was then transferred into tubes containing $9 \mathrm{~mL}$ of RappaportVassiliadis soy broth (RVS) and incubated for $24 \mathrm{hr}$ at $42^{\circ} \mathrm{C}$. A loopful of the growing colony was then streaked onto Salmonella-Shigella Agar (SSA) to obtain pure colony of Salmonella spp. isolates.

\section{Antimicrobial susceptibility tests}

Antibiotic susceptibility tests were conducted using the procedure as recommended by the National Committee for Clinical Laboratory Standards (CLSI 2016). Briefly, a suspension of Salmonella spp. isolates with density equivalent to McFarland 0.5 turbidity standard were evenly spread on the surface of plates containing Mueller Hinton agar (MHA) using a sterile cotton swab. Antibiotic discs (Oxoid, UK) consisting of ampicillin $(30 \mu \mathrm{g})$, penicillin (10 $\mu \mathrm{g})$, amoxicillin $(25 \mu \mathrm{g})$, cefotaxime $(30 \mu \mathrm{g})$, ceftriaxone (30 $\mu \mathrm{g})$, gentamicin $(10 \mu \mathrm{g})$, kanamycin $(30 \mu \mathrm{g})$, streptomycin $(10 \mu \mathrm{g})$, tetracycline $(30 \mu \mathrm{g})$, ciprofloxacin $(5$ $\mu \mathrm{g})$, ofloxacin $(5 \mu \mathrm{g})$, nalidixic acids (30 $\mu \mathrm{g})$, chloramphenicol $(30 \mu \mathrm{g})$, and azithromycin $(15 \mu \mathrm{g})$ were placed on the agar plates before the plates incubated at 37 ${ }^{\circ} \mathrm{C}$ for 18-24 hr. Escherichia coli ATCC $^{\circledR} 25922$ was used as a control microorganism in the tests.

\section{Statistical analysis}

All data were tabulated using Microsoft Excel to generate descriptive information in tables or charts. Statistical analysis was performed using XLSTAT2020 with significant difference was accepted at values of $p \leq 0.05$.

\section{RESULTS AND DISCUSSION}

\section{Bacterial enumeration and isolation}

Salmonella spp. enumeration within water samples collected in both Lamnyong and Krueng Aceh rivers is shown in Figure 2. As shown, there were no significant bacterial densities $/ \mathrm{mL}$ of both locations $(p=0.200)$. On average there was about 441.67 Salmonella spp. MPN/mL in Krueng Aceh as opposed to $20.47 \mathrm{MPN} / \mathrm{mL}$ of Lamnyong river.

Of the sites, in total 57 Salmonella spp. isolates were recovered, i. e. 38 isolates of Lamnyong and 19 isolates of Krueng Aceh. The pure colonies of the isolates are depicted in Figure 3. Salmonella spp. appeared as smooth and opaque or translucent colorless colonies with black centers on Salmonella Shigella (SS) Agar.

\section{Antibiotic susceptibility tests}

The results of antibiotic susceptibility tests are tabulated in Table 1 and the detailed susceptibility information of each isolate is available in supplementary data. It can be seen that Salmonella spp. recovered from Lamnyong and Krueng Aceh showed antibiotic resistance to azithromycin, tetracycline, and streptomycin. Moreover, Salmonella spp. recovered from both sites showed high resistance to ofloxacin, ciprofloxacin, dan ceftriaxone. The classification of the multi-drug resistance (MDR) among isolates is tabulated in Table 2. It is apparently shown that all Salmonella spp. isolates were classified as MDR. Of total isolates, the number of isolates resistant to 4-6 antibiotics was $33(57.9 \%)$, whereas those that were resistant to 7-9 antibiotics and more than 10 antibiotics were $23(40.4 \% \%)$ and $5(8.8 \%)$ respectively.

Table 2. Number (percentage) of multidrug-resistant Salmonella spp. isolates recovered from Lamnyong and Krueng Aceh river, Banda Aceh, Indonesia

\begin{tabular}{cccc}
\hline \multirow{2}{*}{$\begin{array}{c}\text { Number of } \\
\text { resistances }\end{array}$} & \multicolumn{2}{c}{$\begin{array}{c}\text { Number (percentage) of } \\
\text { resistant isolates }\end{array}$} & $\begin{array}{c}\text { Total } \\
(\mathbf{n = 5 7})\end{array}$ \\
\cline { 2 - 3 } & $\begin{array}{c}\text { Lamnyong } \\
\text { river }(\mathbf{n}=\mathbf{3 8})\end{array}$ & $\begin{array}{c}\text { Krueng Aceh } \\
\text { river (n=19) }\end{array}$ & \\
\hline $4-6$ & $25(65.9)$ & $8(42.1)$ & $33(57.9)$ \\
$7-9$ & $11(28.9)$ & $7(36.8)$ & $18(31.6)$ \\
$\geq 3$ & $38(100)$ & $19(100)$ & $57(100)$ \\
$\geq 5$ & $35(92.1)$ & $15(78.9)$ & $50(87.7)$ \\
$\geq 7$ & $13(34.2)$ & $10(52.6)$ & $23(40.4)$ \\
$\geq 10$ & $2(5.26)$ & $3(15.8)$ & $5(8.8)$ \\
\hline
\end{tabular}

Table 1. Number of isolates (\%age) of antibiotic susceptibility of Salmonella spp. recovered from Lamnyong and Krueng Aceh river, Banda Aceh, Indonesia

\begin{tabular}{|c|c|c|c|c|c|c|}
\hline \multirow{2}{*}{ Antibiotics } & \multicolumn{3}{|c|}{ Isolates of Lamnyong river $(\mathbf{n}=38)$} & \multicolumn{3}{|c|}{ Isolates of Krueng Aceh river (n=19) } \\
\hline & Sensitive & Intermediate & Resistance & Sensitive & Intermediate & Resistance \\
\hline Streptomycin & $0(0)$ & $1(2.6)$ & $37(97.4)$ & $0(0)$ & $0(0)$ & $19(100)$ \\
\hline Nalidixic Acid & $5(13.2)$ & $30(78.9)$ & $3(7.9)$ & $6(31.6)$ & $10(52.6)$ & $3(15.8)$ \\
\hline Gentamycin & $0(0)$ & $7(18.4)$ & $31(81.6)$ & $0(0)$ & $14(73.7)$ & $5(26.3)$ \\
\hline Kanamycin & $0(0)$ & $21(55.3)$ & $17(44.7)$ & $2(10.5)$ & $7(36.8)$ & $10(52.6)$ \\
\hline Ciprofloxacin & $33(86.8)$ & $3(7.9)$ & $2(5.3)$ & $10(52.6)$ & $5(26.3)$ & $4(21.1)$ \\
\hline Ceftriaxone & $32(84.2)$ & $3(7.9)$ & $3(7.9)$ & $10(52.6)$ & $5(26.3)$ & $4(21.1)$ \\
\hline Azithromycin & $0(0)$ & $0(0)$ & $38(100)$ & $0(0)$ & $0(0)$ & $19(100)$ \\
\hline Ofloxacin & $36(94.7)$ & $1(2.6)$ & $1(2.6)$ & $17(89.5)$ & $2(10.5)$ & $0(0)$ \\
\hline Tetracycline & $0(0)$ & $0(0)$ & $38(100)$ & $0(0)$ & $1(5.3)$ & $18(94.7)$ \\
\hline Cefotaxime & $20(52.6)$ & $11(28.9)$ & $7(18.4)$ & $9(47.4)$ & $4(21.1)$ & $6(31.6)$ \\
\hline Penicillin G & $6(15.8)$ & $4(10.5)$ & $28(73.7)$ & $2(10.5)$ & $0(0)$ & $17(89.5)$ \\
\hline Chloramphenicol & $3(7.9)$ & $31(81.6)$ & $4(10.5)$ & $4(21.1)$ & $10(52.6)$ & $5(26.3)$ \\
\hline Amoxicillin & 7 (18.4) & $13(34.2)$ & $18(47.4)$ & $6(31.6)$ & $5(26.3)$ & $8(42.1)$ \\
\hline Ampicillin & $14(36.8)$ & $8(21.1)$ & $16(42.1)$ & $6(31.6)$ & $2(10.5)$ & $11(57.9)$ \\
\hline
\end{tabular}




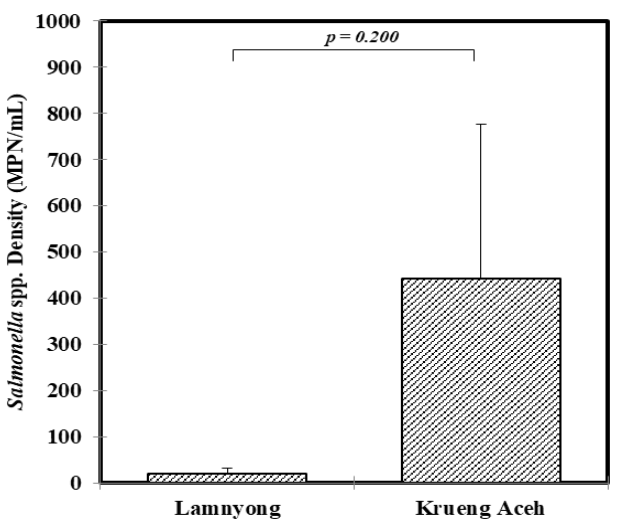

Figure 2. The means of Salmonella spp. cell densities (MPN/mL) in each station

\section{Discussion}

Salmonella-related infections, especially in polluted aquatic systems, remain major concern. The infections generate significant implications in both clinical and non-clinical settings (Hazards 2009; Majowicz et al. 2010). The pathogens have been applied as one indicator microorganisms signify the environmental sanitation or the occurrence of polluted surface water (Levantesi et al. 2012; Kadykalo et al. 2020). In the present study, the isolates of Salmonella spp. in two major rivers of Banda Aceh were recovered and enumerated for their bacterial density. There was no significant difference in bacterial densities of both rivers despite the means of Salmonella spp. density from Krueng Aceh was twenty-two folds higher than Lamnyong river, i.e., 441.67 and 20.47 Salmonella spp. cells/mL, respectively.

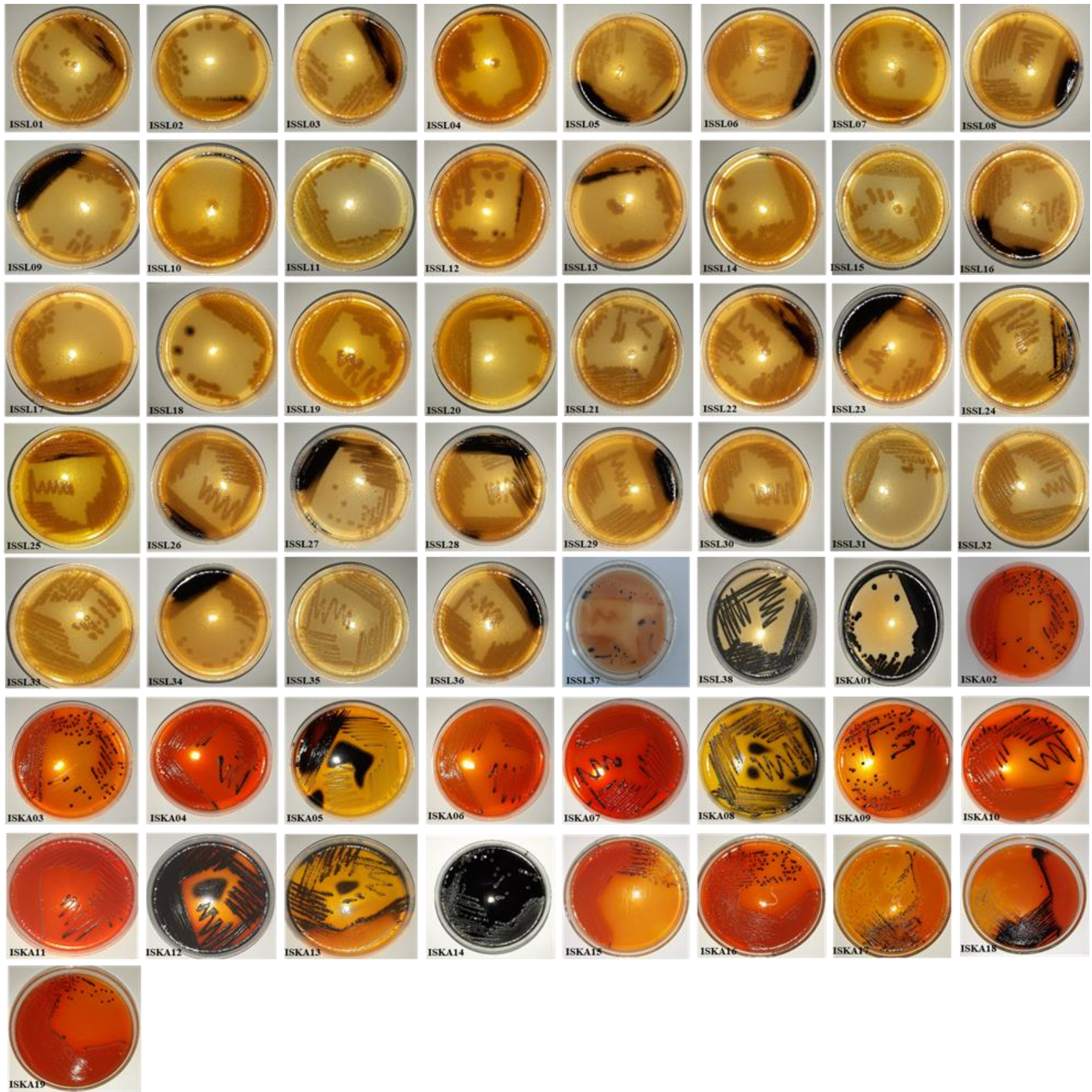

Figure 3. The isolates of Salmonella spp. recovered from sampling stations in Banda Aceh, Indonesia, namely 38 isolates of Lamnyong (coded as ISSL) and 19 isolates of Krueng Aceh (coded as ISKA) grown on Salmonella-Shigella Agar (SSA) selective media 
The insignificant bacterial densities might be due to quite high variability on the bacterial densities among three sampling sites in the Krueng Aceh. Although the size of the Krueng Aceh is smaller than its counterpart, Krueng Aceh receives water input mode dominant from various sources including residentials, home-industries, traditional markets, and hotels than Lamnyong river which lack human activities as it is mainly designated for flood-buffering zone and open-green space area. Previous investigation also suggested that higher human population density and higher load of human waste disposal and poor waste management had a higher tendency to increase Salmonella spp. concentration within aquatic system (Massinai et al. 2019). Additionally, other research also demonstrated that Salmonella spp. densities in water might be influenced by temperature and precipitation variation along with changes in rates of local human and animal population carrying the pathogens (Haley et al. 2009).

In the present study, the isolation of Salmonella spp. was conducted by re-inoculating the colonies grown on XLDA agar that are presumptively different morphological features into new plates containing SSA media to obtain pure colonies. The fact that number of Salmonella spp. isolates recovered from Krueng Aceh $(n=19)$ was half than the number of isolates from Lamnyong river $(\mathrm{n}=38)$ did not necessarily indicate the Salmonella spp. diversity in the first river was less than the later. The diversity might be revealed by further serotyping or molecular identification of the recovered Salmonella spp. isolates which were not performed in the current research. Conversely, it is projected that the diversity of Salmonella spp. collected from Krueng Aceh river will be higher than Lamnyong river since the Krung Aceh crosses areas dominated by human population and activities. Other findings also emphasized the high levels of Salmonella diversity can be viewed in a sense of contamination dynamics dominated by multiple Salmonella sources and the persistence of multiple populations in the environment (Jiménez et al. 2014).

In the present study, the Salmonella spp. isolates were pan-resistant to at least three different classes of antibiotics tested, i.e., streptomycin, azithromycin, and tetracycline, and half of the isolates were resistant to more than five antibiotic classes so that the isolates might be classified as multidrug-resistant (MDR). These findings align with other research demonstrates that Salmonella spp. isolates recovered from surface water of Grand River watershed (south-western Ontario, Canada) were commonly resistant to streptomycin, tetracycline, sulfisoxazole and ampicillin (Kadykalo et al. 2020). Others found Salmonella spp. isolates $(31.2 \%, 16 / 51)$ collected from surface water in the Southeastern United States were commonly resistant to ampicillin, chloramphenicol, streptomycin, sulfamethoxazole, tetracycline, cephalothin, amoxicillin-clavulanic acid, and ceftriaxone ( $\mathrm{Li}$ et al. 2014). Moreover, other investigators also indicated that MDR Salmonella spp. isolates were often detected to be resistant to the quinolone nalidixic acid, streptomycin, and tetracycline (Levantesi et al. 2012).

The emerging MDR Salmonella spp. in aquatic environment might be attributed to the dissemination and persistence of the bacterial pathogens in environmental settings. Salmonella spp. exhibiting MDR determinants harbor antibiotic resistance genes encoded in chromosomes and/or plasmids leading the pathogens to spread their resistance (Eng et al. 2015). For example, mutation of gyrA gene in chromosomes allows Salmonella serotypes to be resistant to quinolones leading to their reduced sensitivity to ciprofloxacin (Chiu et al. 2002). Salmonella serotypes have developed antibiotic resistance by insertion of the corresponding genes into their virulence plasmids allowing the pathogens to be resistant to conventional antibiotics including chloramphenicol, tetracycline, ampicillin, and streptomycin (Guerra et al. 2002). The existence of antibiotic resistance gene within self-transferable plasmids and other mobile genetic elements, such as class 1 integrons, increase their potentials to be disseminated by means of horizontal gene transfer, not only to the same species but also in different species of bacterial pathogens (Guerra et al. 2001; Xu and Chen 2020). In addition to the dissemination, the persistence of Salmonella spp. particularly in the aquatic environment might also play significant role in emerging MDR of the pathogens. Salmonella spp. have the ability to survive through a variety of mechanisms in aquatic settings, including entry to the viable, yet non-culturable (VBNC) condition allowing Salmonella spp. to persist in the environment including harsh condition (Liu et al. 2018).

The prevalence of MDR Salmonella spp. in the current study suggests that rivers remain the major reservoirs for the transmission of the pathogen in aquatic systems. Rivers as well as other surface waters are exposed to environmental activities such as discharge of sewage, runoff, precipitation, animal farming, and wildlife are more prone to be contaminated (Liu et al. 2018). Previous findings signified that the prevalence of the Salmonella spp. Varied, depending on the temporal and spatial changes in the aquatic system (Haley et al. 2009). Overall, understanding the factors affecting the Salmonella spp. density and diversity in the aquatic system are important to reduce the potential health risk of these enteric pathogens. An appropriate assessment and monitoring are necessary to ensure water quality as well as to project and prevent the transmission of waterborne pathogens in the aquatic environment.

\section{ACKNOWLEDGEMENTS}

This study was supported by the Institute of Research and Community Services (LPPM), Universitas Syiah Kuala under the H-indexed Research Grant [No. 269/UN11/ SPK/PNBP/2020].

\section{REFERENCES}

Agustina S, Nuraini SP, Purnawan S, Siregar EEW. 2020. Identifikasi awal sampah apung anorganik di muara Sungai Krueng Aceh, Kota Banda Aceh. DEPIK Jurnal Ilmu-Ilmu Perairan, Pesisir dan Perikanan 9: 131-140. [Indonesian] 
Allen HK, Donato J, Wang $\mathrm{HH}$, Cloud-Hansen KA, Davies J, Handelsman J. 2010. Call of the wild: antibiotic resistance genes in natural environments. Nat Rev Microbiol 8: 251-259.

BPS. 2020. Penduduk, Laju Pertumbuhan Penduduk per Tahun, Distribusi Persentase Penduduk, Kepadatan Penduduk, Rasio Jenis Kelamin Penduduk Menurut Kecamatan di Kota Banda Aceh, 2019. BPS Kota Banda Aceh. [Indonesian]

Chiu CH, Wu TL, Su LH, Chu C, Chia JH, Kuo AJ, Chien MS, Lin TY. 2002. The emergence in Taiwan of fluoroquinolone resistance in Salmonella enterica serotype Choleraesuis. N Engl J Med 346: 413419.

Eng SK, Pusparajah P, Ab Mutalib NS, Ser HL, Chan KG, Lee LH. 2015 Salmonella: a review on pathogenesis, epidemiology and antibiotic resistance. Front Life Sci 8: 284-293.

Guerra B, Soto S, Helmuth R, Mendoza MC. 2002. Characterization of a self-transferable plasmid from Salmonella enterica serotype Typhimurium clinical isolates carrying two integron-borne gene cassettes together with virulence and drug resistance genes. Antimicrob Agents Chemother 46: 2977-2981.

Guerra B, Soto SM, Argüelles JM, Mendoza MC. 2001. Multidrug resistance is mediated by large plasmids carrying a class 1 integron in the emergent Salmonella enterica serotype [4, 5, 12: i:- ]. Antimicrob Agents Chemother 45: 1305-1308.

Hadi I, Suhendrayatna S, Muchlisin ZA. 2018. Status mutu air dan kandungan logam berat pada air dan sedimen di muara Krueng Aceh, Kota Banda Aceh. DEPIK Jurnal Ilmu-Ilmu Perairan, Pesisir dan Perikanan 7: 91-99. [Indonesian]

Haley BJ, Cole DJ, Lipp EK. 2009. Distribution, diversity, and seasonality of waterborne salmonellae in a rural watershed. Appl Environ Microbiol 75: 1248-1255.

Hazards EPoB. 2009. Joint opinion on antimicrobial resistance (AMR) focused on zoonotic infections. EFSA J 7: 1372.

Jiménez M, Martinez-Urtaza J, Rodriguez-Alvarez MX, Leon-Felix J, Chaidez C. 2014. Prevalence and genetic diversity of Salmonella spp. in a river in a tropical environment in Mexico. J Water Health 12: 874-884.

Kadykalo S, Thomas J, Parmley EJ, Pintar K, Fleury M. 2020. Antimicrobial resistance of Salmonella and generic Escherichia coli isolated from surface water samples used for recreation and a source of drinking water in southwestern Ontario, Canada. Zoonoses Public Health 67: 566-575

Levantesi C, Bonadonna L, Briancesco R, Grohmann E, Toze S., Tandoi V. 2012. Salmonella in surface and drinking water: Occurrence and water-mediated transmission. Food Res Intl 45: 587-602.

Li B, Vellidis G, Liu H, Jay-Russell M, Zhao S, Hu Z, Wright A, Elkins CA. 2014. Diversity and antimicrobial resistance of Salmonella enterica isolates from surface water in southeastern United States. Appl Environ Microbiol 80: 6355-6365.

Liu H, Whitehouse CA, Li B. 2018. Presence and persistence of Salmonella in water: The impact on microbial quality of water and food safety. Front Public Health 6. DOI: 10.3389/fpubh.2018.00159.

Majowicz SE, Musto J, Scallan E, Angulo FJ, Kirk M, O'Brien SJ, Jones TF, Fazil A, Hoekstra RM, International Collaboration on Enteric Disease "Burden of Illness" Studies. 2010. The global burden of nontyphoidal Salmonella gastroenteritis. Clin Infect Dis 50: 882-889.

Massinai A, Tahir A, Abu N. 2019. High concentrations of pathogenic Salmonella spp. during the wet season on bathing beaches in Makassar City, Indonesia. IOP Conf Ser Earth Environ Sci 253: 012044. DOI: 10.1088/1755-1315/253/1/012044.

Ochiai RL, Acosta CJ, Danovaro-Holliday M, Baiqing D, Bhattacharya SK, Agtini MD, Bhutta ZA, Canh DG, Ali M, Shin S, Wain J. 2008. A study of typhoid fever in five Asian countries: disease burden and implications for controls. Bull World Health Organ 86: 260-268.

Rath S, Patra B. 2018. Dispersal of antibiotic-resistant bacteria into aquatic environment - an Overview. J Water Pollut Control 1: 1-3.

$\mathrm{Xu} \mathrm{Y,} \mathrm{Chen} \mathrm{J.} \mathrm{2020.} \mathrm{Transfer} \mathrm{of} \mathrm{class} 1$ integron-mediated antibiotic resistance genes from Salmonella enterica of farm fly origin to susceptible Escherichia coli and Salmonella strains. LWT 122: 109013. DOI: 10.1016/j.lwt.2020.109013. 